\title{
Executive Turnover Revisited From an Efficiency Wage Perspective
}

\author{
Pedro Ortín-Ángel ${ }^{1}$ \\ Universidad Autónoma de Barcelona \\ Edificio B \\ 08193 Bellaterra (Barcelona) \\ SPAIN \\ 34- 935811451 (Voice) \\ 34-9358125 55 (Fax) \\ Pere.Ortin@uab.es \\ Albert A. Cannella Jr. \\ Texas A\&M University \\ Department of Management \\ College Station, TX 77843-4221 \\ (979) 845-0329 (Voice) \\ (979) 845-9641 (Fax) \\ acannella@cgsb.tamu.edu
}

The authors gratefully acknowledge the helpful comments of two anonymous reviewers. A first draft of this paper was completed while this author was visiting the Management Department at Texas A\&M with the financial support of the Spanish Ministry of Education and the DGICYT PB 97-0185. Please address all correspondence to him. 


\title{
Executive Turnover Revisited From an Efficiency Wage Perspective
}

\begin{abstract}
We develop theoretical arguments from the efficiency wage model (Shapiro \& Stiglitz, 1984) in order to better understand Fama's (1980) seminal notion that executive labor markets contribute to the alignment of executive and shareholder interests. We show how the efficiency wage model can be integrated with several other theories of executive turnover. Further, the model allows for predictions that have received very little analysis to date, such as the effect of firm risk and executive salaries on turnover. We test predictions from the model on a sample of executives from 280 manufacturing firms observed annually from 1986 to 1992. Our sample includes data on over 12,000 observations and nearly 1,700 employment terminations. The results are consistent with the main predictions of the efficiency wage model. Holding performance constant, boards of directors are less patient with (more likely to dismiss) executives who have lower salaries and those in higher risk firms.
\end{abstract}




\section{INTRODUCTION}

The separation of ownership and control raises significant concerns about executive compensation and governance. The recent scandals at companies like Enron, WorldCom, and AOL/Time Warner, among others, have moved this concern to the front pages of newspapers. Behind each of these cases there seems to be a common story - the senior executives at the companies have made themselves wealthy by carrying out actions that are contrary to the interests of shareholders, causing large financial losses.

A number of academic studies have analyzed the corporate governance mechanisms necessary to prevent cases like those mentioned above. The two most prominent mechanisms considered are executive compensation and executive turnover. The scholarly work has focused on the factors that are associated with different forms of executive compensation (for a review, see Gomez- Mejia \& Wiseman, 1997 or Murphy, 1999) or executive job change, i.e., dismissal or succession (for a review, see Kesner \& Sebora, 1994 or Finkelstein \& Hambrick, 1996, Chapter 6). ${ }^{1}$ Our study links, both theoretically and empirically, these two streams of literature compensation and turnover.

In studies of corporate governance, agency theory is by far the most prominent theoretical framework, and Fama (1980) and Jensen \& Meckling (1976) are the primary references. Fama argues that the alignment of shareholder and executive interests could be perfect if shareholders could (at zero cost) detect actions taken by executives that are not in shareholder interests. In this situation, shareholders would simply use the information to adjust the executive's future earnings stream. However, because it is expensive and difficult to monitor executives, firm performance is used to estimate executive behavior. The past performance stream associated with the executive is used to set future compensation policy as well as the threat of dismissal. For executives, the 
threat of ex poste settling up is a key motivator, and helps to keep their interests aligned with those of shareholders. The two central predictions from Fama (1980) are (1) poor firm performance will lead to executive dismissal; and (2) executive salaries will be contingent on firm-level performance. However, the empirical evidence regarding these two predictions varies considerably. On the first prediction, there is widespread empirical evidence linking a variety of firm performance measures to executive turnover, and widespread agreement that poor firm performance increases the likelihood of executive turnover (Cannella \& Lubatkin, 1993; Kesner \& Sebora, 1994; Murphy, 1999). On the other hand, the prediction that executive compensation should be performance-contingent has received much less empirical support (Baker, Jensen \& Murphy, 1988).

One key problem with Fama's (1980) arguments lies in the issue of linking executive actions to firm-level performance outcomes. Economic models dealing with moral hazard problems (e.g., Holmstrom, 1982; Harris \& Raviv, 1979) offer a clarification of the dilemma. These authors acknowledge that firm performance is a noisy indicator of the extent to which executive actions align with shareholder interests. For example, the bedrock assumption upon which the separation of ownership and control (and therefore, the separation of decision making and risk bearing) is built is the assumption that business involves risk, and therefore outcomes anticipated ex ante may not be realized ex poste. Therefore, according to these authors, when firm-level performance has fallen short of anticipated outcomes, the extent of executive responsibility must be assessed. Thus, this approach differs importantly from both Fama (1980) and Jensen \& Meckling (1976). The assertion that executive culpability must be assessed and cannot simply be inferred is a key divergence from Fama. Additionally, in recognizing that mistakes in executive performance evaluation are inevitable, the moral hazard approach 
acknowledges that executives must bear some firm-level risk, even when ownership and decision making are separate. This conclusion contrasts with Jensen and Meckling (1976).

When the assessment of executive performance is costly, moral hazard theory suggests that other contractual mechanisms, like pay for performance or dismissal policy, can align executive and shareholder interests at low cost (Holmstrom, 1982; Harris \& Raviv, 1979). The efficiency wage literature of Shapiro \& Stiglitz (1984) provides an analytical framework. Closely associated with agency theory, the efficiency wage model begins with the assumption that when principals evaluate agent behavior, they must use uncertain measures of that behavior. Therefore, in order to economize on monitoring expenditures when monitoring is costly, principals can simply establish a threshold of performance acceptability. If performance falls below the threshold, the agent (in this case, the executive) will be dismissed. The executive, of course, understands this policy and behaves accordingly. The extent to which the executive strives to avoid dismissal will hinge on the expected losses associated with job termination. Salary levels are very important, because they are the principal determinant of those expected losses. For this reason, the performance threshold and the level of salary must be coordinated in order to provide an effective and efficient motivation of the agent.

Our study adopts the efficiency wage approach because it permits us to move beyond the traditional agency theory approaches of Fama (1980) and Jensen \& Meckling (1976). Combining the efficiency wage model with other theories, such as power theories (Shen \& Cannella, 2002) or institution theory (Ocasio, 1999), provides an integrated and coherent explanation for many associations which have already received empirical support. Further, this integration also leads to new hypotheses which have not yet received empirical scrutiny. Our key contributions are to clarify the relationship between firm-level risk and executive pay level, and to show how both 
firm-level risk and executive pay level combine to influence the probability of executive dismissal.

In the section that follows, we provide a discussion of the causes behind executive dismissal and use efficiency wage theory to develop hypotheses. In the second section we describe the database and analytical methodology used to test the hypotheses. In the third section, we present the results of our analyses, and the final section provides the discussion and conclusions.

\section{A EFFICIENCY WAGE EXPLANATION OF EXECUTIVE DISMISSAL}

Agency theory is a theory about executive motivation. The issue we raise is why the threat of dismissal motivates executives in a context of imperfect supervision, where poor firm-level outcomes are not necessarily caused by opportunistic behavior. Efficiency wage theory attempts to provide an answer to this question in the context of the contractual relationships between workers and the company (Shapiro \& Stiglitz, 1984; Milgrom \& Roberts 1992, Chapter 9). Although the original work of Shapiro and Stiglitz has focused in the explanation of unemployment in a labor market in equilibrium, in Appendix A the formal efficiency wage model is extended to explain the relationships between firm-level performance and executive turnover. The main features derived in that appendix are described below.

\section{Basic assumptions}

The efficiency wage model, like most analytical work linked to agency theory, is inspired by transaction costs theory and, more specifically, by the value maximization theorem (Coase, 1960; Milgrom \& Roberts 1992: p. 35). The value maximization theorem suggests that any contractual agreement made between boards of directors and executives must be acceptable to 
both sides. In addition, it assumes that both directors and executives desire an agreement that will generate the greatest possible wealth. Both parties agree that the incentive mechanism selected must avoid actions that result in costs for shareholders that are greater than the profits generated by executives.

However, the efficiency wage model does not draw conclusions about who will initiate and implement the incentive mechanism. Executives may make a formal commitment to resign if firm performance falls below a certain level as a means of convincing the board of their good intentions. So, when an executive's employment is terminated, it is very difficult to determine whether this action is voluntary (the executive has left in order to maintain a good reputation for future contracts) or involuntary (the board has acted to guarantee the good behavior of future executives).

While recognizing that job termination can be voluntary or involuntary, we will henceforth adopt the perspective that the board initiates and implements the executive employment contract. One can argue that when the board observes executive actions that are against shareholder interests, directors will dismiss the executives and demand reimbursement for losses caused. However, there appears to be a wide range of actions that cannot be perfectly observed by shareholders or the board. Shapiro \& Stiglitz (1984) assume that there is only one possible action against shareholders interests, and when that action is taken, it can be detected with a certain level of probability, $p$. Under these assumptions, the only way to reduce the dismissal probability is by not taking the action, thus reducing dismissal probability by $p$.

The capacity that executives have to reduce the probability of dismissal through their own actions is not as clear when the model is extended to the situation where there are no restrictions on the number of managerial actions, and boards can establish the dismissal 
probabilities allocated to the different actions ( $p$ is an endogenous variable). Agency theory assumes that managerial actions will affect firm performance, including share prices. So, while understanding that firm-level performance is an imperfect indicator of executive actions, the board of directors can establish a threshold of performance acceptability. By explicitly establishing a specific level, or through the implicit indication of a level through previous dismissals of executives, boards create expectations among current executives about the acceptability of poor performance and the probability of dismissal associated with managerial actions or decisions (see top left cell in Figure 1).

Insert Figure 1 About Here

Managers can reduce dismissal probabilities by increasing their firms' performance. The higher that firm performance is above the threshold, the lower the probability of executive dismissal. But, a given change in firm performance will have different impacts on dismissal probabilities depending on the initial level of the dismissal probability and the risk of the performance measures.

Assuming that firm performance follows a normal distribution, ${ }^{2}$ the reduction in dismissal probability caused by a given increment in expected firm performance (capacity for influence by executives on the probability of being dismissed) decreases as performance increases above the threshold level (highlighted line in the top left cell of Figure 1). On the other hand, in a company without risk, the executives know the exact consequences of their actions on firm performance and, therefore, whether they are going to be dismissed or not. In a company with infinite risk, it does not matter what executives do, firm performance is a result of random factors, so their actions will have no effect on dismissal probabilities. 
The consequence is that managers that secure a given increase in firm performance experience lower reductions in dismissal probability as they move away from (are above) the performance threshold, or (alternatively) as dismissal probability becomes lower, and at companies with greater levels of risk (see the bottom left cell of Figure 1 and Appendix A for more details).

\section{Executive motivation and implications for optimal dismissal policies}

The efficiency wage mechanism motivates executives to exert more effort because they can reduce dismissal probability and dismissal implies adverse economic or social consequences. Following this logic, there are two basic motivational elements - the the punishment involved in dismissal (or reward for staying at the company ${ }^{3}$ ) and the executives' capacity to reduce the probability of dismissal through their own actions which, according to the above explanations, increases with the dismissal probability of the executive and decreases with the risk associated with firm performance.

The board must establish a level of motivation that causes executives to carry out actions that generate costs to shareholders lower than the profits generated. Boards will be conscious of the relations above, and synthesized in Figure 2. With the same level of executive rents (compensation) and dismissal probability, managers will be less motivated in those firms with greater levels of performance risk, and boards can increase the executive motivation by increasing executive rents or dismissal probabilities, or both.

Insert Figure 2 About Here 
If boards have to establish the same motivation level, they will do so by taking into account the risk of firm performance and altering the executive's rents and performance thresholds, or what is the same, the optimal dismissal probabilities. So, given the relationships above, boards will establish higher dismissal probabilities when managers enjoy lower rents, and in firms with similar levels of risk, or in firms with greater levels of risk when managers obtain similar levels of rents.

In summary, the implications deduced from the efficiency wage model developed in the appendix are:

1) Boards of directors will fix minimum firm performance thresholds, and dismiss executives who fail to exceed them. The threshold will depend on the level of motivation that boards desire. For the set of boards that desire a given level of motivation, we should observe different performance thresholds depending upon the level of compensation (the cost of dismissal to the executive) and the risk associated with the firm's strategy (the executive's capacity to influence firm performance) (see Figure 2).

2) Dismissal probability will increase with firm-level risk (the variance in performance). This is because a greater probability of dismissal is necessary under greater risk in order to achieve the same capability for influence by the executives, and therefore the same motivation if executive rents are held constant.

3) Dismissal likelihood should decrease with higher executive rents. Higher rents indicate that the same level of motivation can be obtained with lower capacity of influence by executives on the probability of dismissal. As a consequence of this, it is necessary to reduce the probability of dismissal at companies with a given level of risk. 
4) Ultimately, dismissal is a mechanism for motivating the future behavior of executives, not for correcting poor performance. Therefore, executive turnover is expected to have no influence on subsequent firm performance.

\section{Empirical implications}

It will be very difficult for researchers to know actual performance thresholds and thus to test the model directly. The indirect method of testing these predictions would be to collect data about a set of executive changes and note whether the above relationships are observed, after controlling for other factors that might influence executive rents, dismissals, and performance outcomes. Because we are unable to observe actual profitability thresholds and levels of motivation, we will assume that the profitability threshold is a random variable whose average, in accordance with point 2) above, increases with the noise in performance measurement and, in accordance with point 3), decreases with executive rents.

Once we have controlled for the level of benefits and noise in performance measurement, lower levels of performance imply greater probability that the threshold is not exceeded, and therefore, that dismissal will follow (see Figure 1, top right cell).

\section{Hypothesis 1: $\quad$ The probability of executive turnover is negatively associated with firm} performance.

Hypothesis 1 predicts a frequently observed association between firm performance and executive turnover. This relationship has traditionally been interpreted as evidence that boards of directors are trying to align the interests of executives with those of the shareholders. The efficiency wage model shows that for this to occur, a series of additional relationships synthesized in Hypotheses 2 and 3 below are also necessary. 
In accordance with point 2) above, once we have controlled for the level of executive rents, the probability that the threshold is greater than firm performance is higher in companies with higher risk (see Figure 1, bottom right cell).

Hypothesis 2: $\quad$ The probability of executive turnover is positively associated with the noise in firm performance.

Similarly, in accordance with point 3), once we have controlled for the level of risk in firm performance, the probability that performance will fall below the threshold is lower among firms with higher levels of executive rents (see Figure 1, bottom right cell).

Hypothesis 3: $\quad$ The probability of executive turnover will be negatively associated with the level of executive rents.

Some extensions to the basic model can be made when there are teams of executives. Boards can use additional mechanisms to alleviate some of the information problems associated with executive effort. One mechanism would be to use mutual monitoring as a way of providing peer pressure. When executives work in teams, the possibility of improving team-level results increases the incentives for mutual control among team members. Kandel and Lazear (1992) argue that the effectiveness of this type of peer pressure will be reduced as team size increases, because the marginal value of peer pressure decreases with team size, and because it becomes more difficult to identify free riders as team sizes increases. Because mutual control leads to higher motivation, more mutual control reduces the need for motivation via the dismissal threat and consequently, after controlling for executive rents and risk, we expect lower dismissal probabilities. Therefore, we expect that in larger teams, where mutual control is weaker, there will be greater likelihood of turnover (for further details see extensions of Appendix A).

Hypothesis 4: $\quad$ The probability of executive turnover will be positively associated with the size of the top management team. 
It is important to remember that in the efficiency wage model, dismissal is not an instrument designed to directly resolve poor firm performance. Dismissal, in this model, is an exemplary action, taken to motivate future executives. Therefore, we do not expect improvements in firm performance after executive turnover.

Hypothesis 5: $\quad$ Executive turnover will have no effect on subsequent firm performance.

The predictions of the model seem consistent with previous empirical results in sports team studies (Grusky, 1963; Gamson \& Scotch, 1964; Pfeffer \& Davis-Blake, 1986) and the model may also help explain the persistent observation that succession often does not lead to improved firm performance (for a review, see Warner, Watts, \& Wruck 1988 or Furtado \& Karan, 1990).

\section{Other Explanations of Executive Job Change}

Empirically we only observe executive turnover, but the observed turnover could be caused by a number of different reasons beside the alignment of executive and shareholder interests. In this section we summarize some of these arguments and their implications.

In a world of perfect information, we would expect that firm needs and executive abilities would align perfectly. Rosen (1982) argues that in such a world, executives with greater abilities will occupy jobs with greater responsibility because they are more productive in those jobs. Further, changes in the firm's environment and/or in executive abilities lead to movement through the job allocation process. In this ideal world, there would be a continuous "fit" between the changes observed in the environment, executive abilities, and firm needs.

The literature on internal labor markets draws a completely different picture than that implied by the perfect information scenario (Doeringer \& Piore, 1971). This literature rests on the notion of firm-specific investments, firm-specific human capital in particular, which is of 
zero value outside a particular firm (Becker, 1964; Topel 1991; Castanias \& Helfalt, 1991; 1992; Harris \& Helfalt, 1997). For example, Kotter (1982: p. 60) argues that for the first six months to a year in a job, managers invest most of their time in developing the goals and the objectives of their businesses, largely firm-specific investments. To the extent that firm-specific investments are important we would expect to observe few executives changing employers, because such changes are costly, especially to the executives, who rely solely or largely on their human capital for income. Yet, mobility clearly exists in the executive labor market (Dalton \& Kesner, 1983; Baker et al., 1994a; 1994b). This evidence suggests that although firm-specific investments are important, there must be other explanations.

Leonard (1990) and Baker et al. (1994b) suggest a "learning by doing" process as an explanation of job mobility. This theory was not developed with executives in mind, but rather designed for lower-level workers. Although initially the workers do make firm-specific investments, they also develop other skills, especially over time. These skills can be specific to an industry, such as knowledge of technological aspects, or more general, such as overall social abilities or networks. Movement between jobs, despite the loss of productivity arising from the inability to transfer firm-specific abilities, can be explained by the fact that the worker's generic or industry-specific skills are more productive in other firms than in the present job. Thus, the learning by doing approach predicts that some workers are motivated to change jobs in a search of a better use of their abilities.

The learning by doing approach implies that new jobs will offer better compensation and benefits than old jobs. As noted above, however, this theory was not designed with executives in mind. One problem with extending this model to executives is the overall size of the market, or the number of positions available at any given time. The learning by doing approach assumes 
that there are better positions available for workers to move into. This poses a significant challenge to the model when applied to executives of large public corporations, because it seems unlikely that the availability of better jobs will be adequate to encourage much executive movement. As firm size increases, and as hierarchical level increases, the pool of equivalent or better jobs shrinks.

A final literature stream implies that executive movement is prompted by dramatic shifts in firm strategy. Virany, Tushman \& Romanelli (1992) argue that when strategy changes dramatically, the skills required to design and implement the new strategy are likely quite different than those accumulated by the executives in charge of the old strategy. In this context, the replacement of executives should improve the fit between the firm's needs and executive resources. These arguments have been used to explain why firms sometimes hire outsiders as CEOs (Helmich, 1975; Wiersema, 1992). Empirical evidence suggests that firms strive to fit the abilities of new executives to strategic requirements (Virany et al., 1992; Datta \& Rajagopalan, 1998), and that large shifts in strategy often lead to wholesale replacement of top managers (Virany et al., 1992).

The situations described above are characterized by changes that affect the needs of firms, implying a reorientation in their strategy, or in alternative uses of the executive time, leading to better employment outside the original firm. As in the case of a retirement, there is no prediction about the relationship between poor performance and executive turnover. However, changes such as those described above do lead to a greater probability of executive turnover, so it is necessary to control for these alternative explanations. 


\section{METHODS}

\section{Sample and Data Collection}

The population for this study is publicly traded US manufacturing firms (SIC 2000 through 3999) listed continuously on COMPUSTAT between 1986 and 1992. We first identified all such firms, then ranked them by assets and divided them into 10 deciles. Then, we randomly selected 28 firms from each decile.

Data were collected for the years 1986 through 1992. The primary data source for the executive exit study was the list of current officers and directors provided in each annual report to shareholders. These officer lists provided us with a fiscal year end "snapshot" of the company's executive cadre. Data on executive salaries were gathered from proxy statements. These statements reveal the salaries only of the 5 highest-paid officers in the firm, so many sample executives had no salary information available. Data on company-level annual financial performance (ROA) and industry average financial performance (industry ROA) were gathered from COMPUSTAT. Data on shareholder returns were gathered from the Center for Research on Security Prices (CRSP) tapes. We attempted to gather firm-level data for each year during the observation period. Ideally, we would have data on 1,680 firm-years (280 firms times 6 years

each $^{4}$ ), but missing data (usually missing annual reports or financial information) reduced the final number of firm-years to 1,644 .

The unit of analysis for the study is the executive, not the firm. The original database includes information on 14,045 executive-years. However, missing data (most often the executive's age) reduced the number of observations to 12,805 . We included each officer of a sample firm for each year in which he or she served as an officer. 


\section{Measures}

Executive turnover. For each executive-year, we dummy coded a variable, exit, to indicate the presence or absence of a turnover during the following fiscal year. For this reason, the final year of observation for each firm is used only for this purpose, and does not comprise part of the sample analyzed. This permits us to establish temporal precedence (performance occurs before turnover), which we felt was essential to a rigorous test of our hypotheses. We identified 1,694 cases in which the executive's employment terminated in the following year (exit=1), and these comprise about $13 \%$ of the observations.

Firm performance. We use two measures of firm performance..$^{5}$ The first, Return On Assets (ROA), is a commonly used and well-understood measure of firm performance particularly appropriate for manufacturing firms (e.g. Boyd, 1994; Cannella \& Lubatkin, 1993). We calculated each firm's ROA as income before extraordinary items and discontinued operations divided by net assets as reported during each fiscal year. ${ }^{6}$ Our second performance measure was shareholder return. We calculated this measure by compounding the daily returns reported on the Center for Research on Securities Prices (CRSP) tapes during each fiscal year. These returns are adjusted for dividends and stock splits, so the compounded return measure accurately reflects the returns shareholders have realized at the end of a fiscal year from a $\$ 1.00$ investment made on the first day of the fiscal year.

Relative performance. Some authors (Holmstrom, 1979; Lambert \& Larcker, 1987) argue that additional information related to firm performance can help improve the evaluation of executive effort. For this purpose we include the industry average return on assets for the year (industry ROA) and the average stock market return for the fiscal year ${ }^{7}$ (market return) from CRSP. Industry ROA is at the two-digit Standard Industrial Code (SIC) level. Market return is the adjusted stock return for a fully diversified portfolio during the firm's fiscal year. 
Firm risk. Our primary risk measure ${ }^{8}$ is the standard deviation in daily returns during the year of the observation from CRSP. Following the usual convention, we refer to this measure as total risk.

Executive salary. Salary is measured in dollars, and refers only to cash compensation, comprised of salary and cash bonuses. It does not include information about share ownership or stock options. Although more information it is always welcome, we believe that the lack of ownership information will not have important implications in our tests, as shares or stock options will usually remain in the possession of the executives after employment is terminated. What the theory proposes to measure is the compensation the executive loses due to employment termination.

We log transformed salary for our analyses. We refer to the final measure as log(salary). Unfortunately, as implied above, many of the salaries are missing (at best, salaries are publicly available only for the 5 highest paid executives in publicly-traded companies). For this reason, we conduct some analyses only among the 5,761 executive-years for which salary information is available.

Top management team size. TMT size is number of officers reported for the firm in the given year. This is a standard measure in the literature about top management teams (Hambrick, 1994).

Control variables. A critical concern in our analyses is to control for the fact that a key reason for executive job termination is retirement. Although it is difficult to know if a turnover represents a retirement, we control for this concern by including the age of the executive in the analyses. 
As argued by Leonard (1990) and Baker et al. (1994b), executives learn by doing on the job and improve their abilities over time. However, sometimes internal promotion is blocked because all the positions ahead of the executive are filled. When the firm's top officer (typically the $\mathrm{CEO}$ ) is of advanced age, it increases the probability that younger executives may soon move up in the hierarchy. To control for this alternative, we include a measure of the incumbent CEO's age - CEO age.

Firm-specific investments have been argued as a reason to stay with a single employer. Following this logic, an executive's tenure at the firm will be correlated with the level of specific investments accumulated. Unfortunately, we could not gather complete information on firm tenure. We instead substituted observation in our sample for this measure. An executive's tenure can be divided into two intervals - the years in the firm before the observation period, and the years in the firm during the observation period. We only have information about this second measure. We refer to this measure as sample tenure. Zero values of sample tenure can have two meanings: 1) the executive is new to the firm; 2) the executive is not new in the firm but is new in the sample. Therefore, we included an indicator variable (new) with a value of one for executives who are left-censored by the observation window.

Firms in different economic sectors can suffer different shocks that increase or decrease the demand for executives and variations in observed performance, and consequently the level of executive turnover. A total of 28 dummy variables were created to control for fixed industry effects at the 2-digit SIC level. We refer to these 28 dummy variables collectively as industry controls.

Information is available about the titles held by each executive, and our sample includes a total of 40 different titles. We classify the executives into one of 5 levels in accordance with the 
importance of the title held. Appendix B provides a breakdown of titles and their associated levels. Our 5 categories are top officer, which is held by one and only one executive for each firm year level 1, which includes Presidents and other very senior titles; level 2; level 3, and level 4. The final category (level 4) comprises about $10 \%$ of the sample and is the category omitted in most analyses.

Finally we control for the size of the firm, measured by the $\log ($ assets) and $\log ($ sales $)$, where both assets and sales are measured in millions of dollars.

\section{RESULTS}

Table 1 provides basic descriptive statistics for two samples. The first 2 columns provide means and standard deviations for the overall sample, while the second 2 columns provide corresponding statistics for the sub-sample with complete data on executive salaries. The table indicates that shareholder return (14\%) is quite a bit larger than ROA (3\%). Further, shareholder return is about 7 points lower than the average market return (22\%). The two samples (the full sample and the salary sub-sample) post very similar numbers across the variables in Table 1. Perhaps the greatest difference is that the salary sub-sample (not surprisingly) consists of more senior executives than the full sample. This is because salaries are publicly available only for the 5 highest paid executives in the firm.

\section{Insert Table 1 About Here}

What Table 1 does not indicate clearly is the age distribution of executives terminating their employment. The average age of executives in the sample, as indicated in Table 1, is 50.8, but the average age of the executive whose employment ends (exit=1) is 52 . The median age of exiting executives is also 52. Further, while retirements are clearly an important part of the 
sample, as the modal age of exiting executives is 64 , only $16.3 \%$ of the exiting executives are of age 63 or greater. To rephrase for emphasis, when only executives in their final year of employment are considered, the average age is 52 , and less than $17 \%$ of this group is aged 63 or older. Clearly, retirements are not the most frequent cause of executive exits in our sample.

\section{The Likelihood of Dismissal}

To test hypotheses related to dismissal probabilities (Hypotheses 1-4) we selected a discrete-time event-history approach (Allison, 1984). This permits us to model each year's exit probability as a function of the previous year's observed performance and context, and to update the independent variables each year. We used logistic regression models with observations corresponding to executive-years, the dependent variable exit (coded 0 or 1), and the independent variables discussed above.

Table 2 presents the results of our analyses. Model 1 includes the independent variables described above without industry controls, comparative measures of performance (industry ROA, market return) or $\log ($ salary). Model 2 includes the industry control variables and comparative measures of firm performance, while Model 3 includes the salaries. Note that in Model 3, the sample is restricted to those executives with salary data, which is less than half of the overall sample.

Insert Table 2 About Here

Hypothesis 1 predicts that the probability of dismissal will be negatively associated with firm performance. As predicted, the coefficients associated with ROA and shareholder return are negative and significant in both Models 1 and 2 of Table 2. For example, in Model 1 the respective coefficients are $-.619, \mathrm{p}<.01$; and $-.171, \mathrm{p}<.01$. The turnover probability is reduced 
from the $13.2 \%$ estimated for the average value of all the independent variables to a $13.1 \%{ }^{9}$ when both measures of firm performance increase one percentage point. This evidence provides support for Hypothesis 1.

Model 2 includes the industry dummy variables, industry ROA, and market return as control variables. The inclusion of these control variables has little impact on the other reported coefficients. Industry ROA is just significant at the $5 \%$ level, but both market return and the set of industry dummy variables are significant at the $1 \%$ level.

In Model 3, which is restricted to the sub-sample for which there is salary data, shareholder return is no longer significant. Further, the size of the coefficient associated with ROA is nearly double that of the regular sample. To see whether this was due to sampling differences or the inclusion of $\log$ (salary) in the model, we ran the analysis again without $\log$ (salary). The observed coefficient for ROA changed very little. We also tested for alternative explanations, such as the low representation of executives from level 4, but the estimates of Model 1 and 2 also changed very little when these executives were removed. This suggests that the change in the size of the ROA coefficient is due to other sample differences between the overall sample and the salary subsample.

Hypothesis 2 implies that the probability of executive dismissal will be positively associated with firm risk. The coefficients associated with total risk are, in all models, positive and significantly different from zero. Evaluated at the average value of all the variables, an increase of one per cent in total risk increases the turnover probability to $14.6 \%$ in Model 1 , an increase of 1.4 percentage points. Results for Models 2 and 3 are very similar. This evidence provides strong support for Hypothesis 2. 
Hypothesis 3 predicts that an executive's probability of dismissal will be inversely associated with salary. The coefficient associated with $\log$ (salary) in Model 3 is negative and significant $(\mathrm{B}=-.22 ; \mathrm{p}<.05)$. Evaluated at the average value of all the variables, an increase of one percent in an executive's salary reduces turnover probability by .03 percentage points. This evidence provides support for Hypothesis 3.

Hypothesis 4 argues that larger top management teams lead to a greater likelihood of turnover. The coefficients associated with TMT size are positive and significant in all 3 models in Table 2. Evaluated at the average value of all the variables, one additional member of the TMT implies a reduction of around .04 percentage points in the turnover probability for the team members. Thus, Hypothesis 4 receives strong support from the evidence reported.

The control variables provide some interesting (and expected) results. Executive age is positive and significant, probably indicating a retirement effect. The coefficient associated with top officer age is also negative and significant, suggesting a tendency for fewer exits as the incumbent nears retirement. The coefficient for sample tenure is negative and significantly different from zero in all the models estimated, suggesting that executive tenure could help to reduce dismissal probabilities. The coefficients for top officer are consistently negative and significant, indicating that the CEO is less likely to depart than executives at level 4 (the category omitted). However, coefficients associated with levels 1 and 2 are not significantly different from those of level 4. Also, coefficients associated with level 3 are positive and significant, indicating that executives from level 3 are actually more likely to exit than those in level 4. Thus, hierarchical position seems to affect dismissal probabilities. The CEO faces a lower likelihood of exit than other officers of the firm. We also test for different sensitiveness of dismissal probabilities to performance and risk measures among hierarchical levels, but none 
were significant. The coefficients associated with firm size, $\log ($ assets $)$ and $\log (\operatorname{sales})$ are consistently insignificant, indicating that firm size has no effect on turnover likelihood among executives. Finally, the set of coefficients associated with the industry controls and the year when the observation was collected are significantly different from zero, indicating oscillations in the proportion of executive turnovers across industries and years.

\section{Consequences of Dismissal on Firm Performance}

The efficiency wage model explains executive dismissal as an exemplary action for the executives and consequently without direct consequences for the future results of the firm (Hypothesis 5). To test this hypothesis we take as unit of analysis the firms, working with an incomplete panel of 264 firms and 1,264 observations between 1987 to 1991 . We compare the changes in performance of three different kinds of firms: those that have changed their top executive once during the sample period; those with more than one top executive change (various changes); and those without any changes of top executive during the sample period. Those with no changes comprised the omitted category in our analysis.

For those firms with only one change, we codify the different years in reference to the turnover year, year 0 . We use the dummy variable year 1 to indicate the year following the turnover, and the dummy year -1 to indicate the year before the turnover. The dummy variables After year 1 and Before year -1 capture the other years. Table 3 shows the determinants of the annual firm performance measures, shareholder returns and return on assets (ROA).

Insert Table 3 About Here 
Among the temporal dummy variables, the only significant performance effect is for shareholder returns during the year of the turnover. Evidence in Table 3 implies that shareholder returns are $19.3 \%$ greater in firms without a top executive turnover relative to all other categories The other important result is that those firms with more than one turnover during the sample period have lower ROA ( $\mathrm{p}<.05)$.

The market value has usually been interpreted as the expected present value of the future profits of firms. The results obtained in Table 3 seems to indicate that top executive dismissals do not affect the real future profits of the firm, but instead effect the expected value of the firm's future returns. Our interpretation is that the dismissal of top executives gives information to the market. Before top executive dismissal, the market agents expect that the firm will take action against the executive because it is optimal according to the efficiency wage model. If no dismissal occurs, the market punishes the firm because the firm is reducing pressure on its top management. Consequently the dismissal increases the market value of the firm (shareholder return) with little modification to real future performance (ROA). Murphy and Zimmerman (1993), using a similar methodology, did not find significant differences in shareholders returns the turnover year, so further empirical research is needed to confirm our results.

\section{DISCUSSION}

A great deal of literature associated with agency theory has considered dismissal as a way to align executive and shareholder interests. Efficiency wage theory helps to better understand this argument and how it would work in real settings. Because there are always information problems, directors have no exact measures of executive performance, and must therefore use only imperfect measures to estimate performance. An efficient way to proceed is to establish a 
threshold level of performance that will be tolerated, and dismiss executives when performance falls below the threshold.

The efficiency wage model captures the key variables that are critical for directors when establishing salary levels and performance thresholds. Directors must decide the limits of acceptable poor performance, but in coordination with the quality of the performance measures and the level of salary provided. Therefore executives of poor performing firms have greater probabilities of dismissal, and the probabilities increase with the risk of the performance measure and decrease with the level of executive salary. We extended the model to include mutual monitoring through teamwork and we control for the effects of hierarchical level in the empirical analysis.

Our empirical tests analyzed the determinants of executive dismissal by focusing on the variables highlighted by the efficiency wage model. In general we find support for the predicted relationships. As has been reported in other empirical work, poor performance is an important determinant of executive turnover (Kesner \& Sebora, 1994; Murphy, 1999). Our results suggest that both accounting and shareholder returns are important for evaluating executive performance.

As argued by the efficiency wage model, dismissal policies will align executive and shareholder interest more efficiently if they are coordinated with compensation policies and the firm's risk profile - hypotheses largely untested previously. The effect is due to the fact that the executive's economic motivation to reduce dismissal probabilities depends on these two variables. For example, when performance improves by $1 \%$, the reduction in dismissal probability is 10 percent greater for those executives in firms with a risk of $0.1 \%$ greater, or a salary 5\% lower than the average. Consequently we find that executives who work at risky firms, 
and those who are relatively low paid, after controlling for firm performance, have greater probabilities of dismissal.

The data also supports the notion that boards of directors may combine different mechanisms to align executive and shareholder interests, such as the peer pressure of colleagues. This evidence should be extended in future work to test the reduction of dismissal probabilities at firms with a greater use of other incentive mechanisms, such as the sensitivity of pay to performance. Future research should also check to see if the results we report are robust to the introduction of variables such as stock ownership or stock option compensation. We also find some evidence that hierarchical position can affect dismissal probability, in the sense that executives in lower hierarchical positions tend to be dismissed first. Theoretical models could be developed in order to consider differences in dismissal policies across hierarchical levels.

We have controlled for several alternative explanations of executive exit. We controlled for retirement through consideration of executive age. We controlled for advancement potential by the age of the incumbent CEO. Finally, our results suggest that longer-tenured executives are less likely to turnover than shorter-tenured ones. We explain this fact by an expected relationship between executive tenure and firm-specific human capital.

Turnover has often been assumed to be a punishment, but there has been little examination of the consequences of dismissal on executives. For each of the 1,694 executives who terminated their employment with a sample firm during our observation period, we looked among the roster of executives of public firms (Compact Disclosure database) to see if they could be found among the officer lists of publicly traded firms. We looked for 2 consecutive years after the executive's employment was ended, and we were able to find only 139 of the terminated executives with another public corporation. We then gathered data on the new firms 
where the executives were found as well as their hierarchical positions and salaries. We were able to gather performance data on only 128 of the new employers, so analyses using performance comparisons between old and new firms were even smaller than the "found" sample of 139. Even more disappointing, we were able to find salary information on only a very small proportion of the re-employed executives. Working with estimated salaries based on the executive job positions, we compute a $7 \%$ reduction on salaries among re-employed executives. Obviously, more rigorous research is needed to confirm the existence of a punishment associated with dismissals, as these first results seem to suggest.

Finally, we do not find a clear improvement in accounting performance after executive turnover, but the turnover policy seems to be positively valued by the stock market compared with the continuity option, reinforcing the applicability of the model.

The efficiency wage model is a normative model that allows us to develop a series of predictions regarding other actions that firms should take to make the dismissal of executives an effective motivator for remaining or future executives. The empirical evidence corroborates most predictions, but the variables used only explain a small part of management rotation. In this sense, as highlighted in recent articles (e.g. Shen \& Cannella, 2002) theories on the influence of power in organizations could increase the spectrum of variables to be analyzed. In fact, these theories could complement each other. Efficiency wages could also be interpreted as a modelization of the process of the loss of power of top executives in the eyes of the board of directors.

The efficiency wage model does not explain how boards come to implant dismissal policies. The institutional theory of action has recently been applied to this type of event (Ocasio, 1999). Efficiency wages, in this situation, could be interpreted as a prediction of the types of 
rules that are ultimately imposed, but no prediction is evident regarding how that process is articulated. Perhaps future research can integrate these different lines of theory.

\section{CONCLUSIONS}

The efficiency wage model is a normative model that could help to improve the alignment of interests between executives and shareholders. This theory postulates that dismissal policies are more efficient when they are coordinated with compensation strategies, taking into account the information problems that arise when inferring executive performance from firm performance. The evidence presented supports the theoretical arguments but also emphasizes the need to extend the model to include other factors, such as the existence of firm-specific investments, the existence of overlapping agency relationships as internal monitors or controls, and some alternative methods of executive supervision and motivation, like pay for performance compensation. Further work is, of course, needed to complement and extend the evidence and theory presented here.

\section{NOTES}

${ }^{1}$ The economics literature has also analyzed these issues. See Murphy (1999) for a recent synthesis.

${ }^{2}$ This relationship will exist for whatever continuous distribution function where the probability level decreases as we move away from its average point.

${ }^{3}$ In fact, the efficiency wage model can be applied to analyze any situation where there is a fixed premium if certain requirements are fulfilled - for example bonuses for reaching certain standards or objectives.

${ }^{4}$ As explained in detail later, the final year of the firm in the dataset was used to determine turnover, but could not be used as part of the sample analyzed.

${ }^{5}$ We also ran analyses on risk-adjusted performance, and achieved very similar results. All the analyses cited but not presented in the text are available upon request. 
${ }^{6}$ The theory does not specify the temporal limits of the performance measures. The accumulation of firm performances referred to different years has not significantly improved the empirical tests and forces us to reduce the number of observations. We will work with annual performances.

${ }^{7}$ We also ran some analyses using market returns for weighted industry portfolios. Because the market returns variable was not significant, we omitted it.

${ }^{8} \mathrm{We}$ also ran some analyses using measures such as unsystematic risk, or the variance of annual market returns and returns on assets. The results were essentially the same as those reported here, and because these measures were very highly correlated, se elected to use only one of them.

${ }^{9}$ In all the cases the dismissal probability has been computed when the rest of variables take their average value. In the case of Models 2 and 3 the reduction is very similar to the mentioned above, around $0.1 \%$.

\section{REFERENCES}

Allison, P.1984. Event History Analysis. Newbury Park, CA: Sage.

Baker, G., Gibbs, M., \& Holmstrom, B. 1994 a. The internal economics of the firm: Evidence from personnel data. The Quarterly Journal of Economics, 109: 881-919.

. 1994 b. The salary policy of a firm: Evidence from personnel data. The Quarterly Journal of Economics, 109: 921-955.

Baker, K., Jensen, M., \& Murphy, K. 1988. Compensation and incentives: practice vs. theory, Journal of Finance, 43: 593-616.

Becker, G. 1964. Human Capital. New York: Columbia University Press.

Boyd , B.K. 1994. Board control and CEO compensation. Strategic Management Journal, 15: 335-344.

Cannella, A.A., Jr., \& Lubatkin, M.H. 1993. Succession as a sociopolitical process. Academy of Management Journal, 36: 763-793.

Castanias, R.P., \& Helfalt, C.E. 1991. Managerial resources \& rents. Journal of Management, 17: $155-171$.

Castanias, R.P., \& Helfalt, C.E. 1992. Managerial \& windfall rents in the market for corporate control. Journal of Economic Behavior \& Organization, 18: 153-184.

Dalton, D. \& Kesner, I. 1983. Inside/Outside succession and organizational size: The pragmatics of executive succession. Academy of Management Journal, 28: 749-762. 
Datta, D.K., \& Rajagopalan, N. 1998. Industry structure \& CEO characteristics: An empirical study of succesion events. Strategic Management Journal, 19: 833-852.

Doeringer, P., \& Piore, M. 1971. Internal labor markets \& manpower analysis. Lexington, Mass: D.C. Jeath \& Co.

Fama, E.F. 1980. Agency problems and the theory of the firm. Journal of Political Economy, 88: 288-307.

Finkelstein, S., \& Hambrick, D.C. 1996. Strategic Leadership. Top executives \& their effects on organizations. St. Paul, Minneapolis: West Publishing Company.

Furtado, E., \& Karan, V. 1990. Causes, consequences \& shareholder wealth effects of management turnover: A review of the empirical evidence. Financial Management, 19: 60-75.

Gamson, W.A., \& Scotch, N.A. 1964. Scapegoating in baseball. American Journal of Sociology, 70: 69-72.

Gomez- Mejia, L.R., \& Weisman, R.M. 1997. Reframing executive compensation: An assessment \& outlook. Journal of Management, 23: 291-374.

Grusky, O. 1963. Managerial succession \& organizational effectiveness. American Journal of Sociology, 69: 21-31.

Hambrick, D.C. 1994. Top Management Groups. In L.L. Cummings \& B.M. Staw (eds.), Research in organizational behavior, vol. 16, 171- 213. Greenwich, CN: JAI Press.

Hambrick, D.C., \& Finkelstein, S. 1987. Managerial discretion: A bridge between polar views of organizations. In L.L. Cummings \& B.M. Staw (eds.), Research in organizational behavior, vol. 9, 369-406. Greenwich, CN: JAI Press.

Harris, D., \& Helfalt, C. 1997. Specificity of CEO human capital \& compensation. Strategic Management Journal, 18: 895-920.

Harris, M., \& Raviv, A. 1979. Optimal incentive contratcts with imperfect information. Journal of Economic Theory, 20: 231-259.

Helmich, D.L. 1975. Corporate succession: An examination. Academy of Management Journal, 3: 429-441.

Holmström, B. 1979. Moral hazard \& observability. Bell Journal of Economics, 10: 74-91.

1982. Managerial incentive schemes -a dynamic perspective. In Essays in Economics \& Management in Honor of Lars Wahlbeck, 209-230. Helsinki: Swenska Handelshögkolan.

Jensen M.C., \& Meckling, W. 1976. Theory of the firm: Managerial behavior, agency costs, \& ownership structure. Journal of Financial Economics, 3: 305-60. 
Kandel, E., \& Lazear E.P. 1992. Peer pressure \& partnerships. Journal of Political Economy, 4: 801-817.

Kesner, I.F., \& Sebora, T.C. 1994. Executive succession: Past, present \& future. Journal of Management, 20: 327-72.

Kotter, J.P. 1982. The general managers. New York: Free Press.

Lambert, R.A., \& Larcker, D.F. 1987. An analysis of the use of accounting \& market measures of performance in executive compensation contracts. Journal of Accounting Research, 25: 85129.

Leonard, J. 1990. Executive pay \& performance. Industrial \& Labor Relations Review, 43: 1329.

Milgrom, P., \& Roberts, J. 1992. Economics, Organization \& Management. Englewood Cliffs, NJ : Prentice Hall.

Murphy, K. 1999. Executive Compensation. In O. Ashenfelter \& D. Card (eds.), Handboolk of Labor Economics, vol. 3, 2485-2563, North-Holland: Elsevier.

Murphy, K., \& Zimmerman J. 1993. Financial Performance surrounding CEO turnover. Journal of Accounting and Economics, 16 : 273-315.

Ocasio, W. 1999. Institutionalized Action and Corporate Governance: The Reliance on Rules of CEO Succession. Administrative Science Quarterly, 44: 384-416.

Pfeffer, J., \& Davis-Blake, A. 1986. Administrative succession \& organizational performance: How administrator experience mediates the succession effect. Academy of Management Journal, 29: 72-83.

Rosen, S. 1982. Authority, control, \& the distribution of earnings. The Bell Journal of Economics, 13: 311-323.

Rosen, S. 1992. Contracts \& the market for executives. In L. Werin \& H. Wijkander (eds.), Contract Economics, 181-211, Oxford: Basil Blackwell Ltd.

Shapiro, C., \& Stiglitz, J. 1984. Equilibrium employment as a worker discipline device. American Economic Review, 74: 433-444.

Shen, W., \& Cannella, A.A. Jr. 2002. Power dynamics within top management and their impacts on CEO dismissal followed by inside succession. Academy of Management Journal, 45: 11951206.

Topel, R. 1991. Specific capital, mobility, \& wages: Wages rise with the job seniority. Journal of Political Economy, 99 : 146-176.

Topel, R., \& Ward, M. 1992. Job mobility ant the careers of young men. Quarterly Journal of 
Economics, 107: 439-479.

Virany, B., Tushman, M., \& Romanelli, E. 1992. Executive succession \& organization outcomes in turbulent environments: An organizational learning approach. Organizational Science, 3: 7291.

Warner, J.B., Watts, R.L., \& Wruck, K.H. 1988. Stock prices \& top management changes. Journal of Financial Economics, 20: 461-92.

Wiersema, M.F. 1992. Strategic consequences of executive succession within diversified firms. Journal of Management Studies, 29: 73-94. 


\section{APPENDIX 1 \\ An Extension of the Efficiency Wage Model}

\section{The social efficient effort}

Assume that company profits $P$ before paying top executive compensation $w$, can be expressed in accordance with the effort of the executive $(e \geq 0)$ and other factors that he or she does not control, $P=\mathrm{g}(e)+x$, where $x$ is a random variable that is distributed like a normal one with mean equal to zero and a variance of $\sigma^{2}$. The expected profits $\mathrm{g}(e)$ increase with the effort $\mathrm{g}^{\prime}(e)>0$, and in order to assure an interior solution we assume that $\mathrm{g}^{\prime}(0)>1$, g' $(e)<0$ and $g(0)=0$ to guarantee that optimal profits will be positive. The executive's effort supposes a cost, $e$, so if either the company owners or the executive are neutral to risk ( $w-e$ is the executive utility function), both would agree to the maximum level of effort $e^{*}$ to be made, $e^{*}=\operatorname{argmax}\{\mathrm{g}(e)-e\}$, and consequently $g$ ' $\left(e^{*}\right)=1$. The level $e^{*}$ maximizes the profits of the firm subject to the participation restriction:

$$
\begin{aligned}
& \operatorname{Max}_{\mathrm{e}}: \mathrm{E}(P)-\mathrm{E}(w) \\
& \text { Subject to: } \mathrm{E}(w)-e=\bar{U} \quad \text { where } \bar{U} \text { is the reserve utility. }
\end{aligned}
$$

The effort $\mathrm{e}^{*}$ also is the solution to the utility maximization problem of the executives subject to guarantee a certain level of expected profits, $\bar{P}$, to the firm, for further details see for example Milgrom \& Roberts (1992, ch. 7). If the effort is not observable or contractible, the executive will not exert effort, $e=0$. Different solutions have been proposed to this situation. The executives can buy all the shares of the firm if they have enough richness or tournaments can be used to rank executives that do similar tasks. Another alternative are dismissal policies.

\section{How can the said effort be implanted?}

Most articles on top executive turnover, referring to the agency theory, assume that dismissal can be a mechanism for achieving the said levels of effort. If the dismissal includes a penalty for the executive, the firm might establish a minimum profit level, $T$, such that if the profit obtained is greater than this level, the executive stays in the company, and if it is lower, he or she is dismissed. The probability of that happening can be expressed as:

$$
p=\operatorname{Prob}(P<T)=\operatorname{Prob}(x<T-g(e))=\operatorname{Prob}(\mathrm{z}<(T-\mathrm{g}(e)) / \sigma)=\mathrm{F}((T-\mathrm{g}(e)) / \sigma),
$$

where $\mathrm{z}=x / \sigma$ and $\mathrm{F}$ is therefore the function of normal accumulated distribution of mean zero and a variance of one.

\section{The behavior of the executive}

The executive will decide on the level of effort that maximizes his or her well-being, considering that the greater the effort, the lower the probability of dismissal. Executives receive rents in their present job, $r>0$, that they will lose in the case of being dismissed (see Shapiro and Stiglitz (1984) for a more complete discussion of the forms that the said rents can take). So if $s>0$ is the compensation received by the executive in the case of being dismissed, and $s+r$ in the case of being in the firm, the expected compensation of the executive will be $\mathrm{E}(\mathrm{w})=(s+r)(1-p)+s p$.

So the executive will exert the effort that maximizes his utility, $\operatorname{Max}_{\mathrm{e}} \mathrm{E}(w)-e$, taking into account the threshold $T$ and the rents $r$ fixed by the firm and its profit risk, $\sigma$. 
The first order condition for a local maximum of the problem above is fulfilled when $\mathrm{f}((T-\mathrm{g}(e)) /$ $\sigma) \mathrm{g}^{\prime}(e)=\sigma / r$, where $\mathrm{f}$ is the density function of the normal distribution with a mean equal to zero and unitary variance. The second order condition for a local maximum is fulfilled when: $r\left(\mathrm{f}((T-\mathrm{g}(e)) / \sigma) \mathrm{g}^{\prime \prime}(e) / \sigma-\mathrm{f}^{\prime}((T-\mathrm{g}(e)) / \sigma) \mathrm{g}^{\prime}(e) \mathrm{g}^{\prime}(e) / \sigma^{2}\right)<0$.

Take note that a priori the first order condition can have more than one solution. In that cases nothing guarantees that the local maximum is the global one.

\section{The firm's problem}

The firm should determine the threshold of profits $T$ and the rents $r$ to give executives an incentive to make an effort of $\mathrm{e}^{*}$, taking note that $g^{\prime}\left(e^{*}\right)=1$.

They can obtain it fulfilling conditions i) and ii):

i) $T=-\sigma\left|\mathrm{f}^{-1}(\sigma / r)\right|+\mathrm{g}\left(e^{*}\right)$, where $\left|\mathrm{f}^{-1}(\sigma / r)\right|$ is the absolute value of the inverse function of the density function of a normal zero-one.

Take note that in this case, $\left(T-\mathrm{g}\left(e^{*}\right)\right) / \sigma=-\left|\mathrm{f}^{-1}(\sigma / r)\right| \leq 0$. So when $\mathrm{f}(z)$ is only defined for $z \leq 0$, $\left|\mathrm{f}^{-1}(\sigma / r)\right|=\mathrm{f}^{-1}(\sigma / r)$.

ii) $\sigma / r \leq \mathrm{f}\left(\mathrm{g}\left(e^{*}\right) / \sigma\right)$.

Condition ii) guarantees that $\mathrm{f}^{-1}(\sigma / r)$ is defined, due that $\sigma / r \leq \mathrm{f}\left(\mathrm{g}\left(e^{*}\right) / \sigma\right) \leq \mathrm{f}(0)$, and consequently condition i) assures that $\mathrm{e}^{*}$ is a local optimum due that fulfills the first and second order conditions of the executive's utility maximization due that $\mathrm{g}^{\prime}\left(\mathrm{e}^{*}\right)>0, \mathrm{~g}^{\prime \prime}\left(\mathrm{e}^{*}\right)<0$ and $\mathrm{f}^{\prime}(\mathrm{T}$ $\left.\left.\mathrm{g}\left(\mathrm{e}^{*}\right)\right) / \sigma\right) \geq 0$ when $T-\mathrm{g}\left(e^{*}\right) \leq 0$.

Condition ii) also implies that $T \leq 0$ what assures that for all the relevant efforts (e $\geq 0)$ we will have that expected firm profits will be greater than the threshold, $T$-g(e) $\leq T \leq 0$ due that $\mathrm{g}(0)=0$, and consequently fulfill the second order condition, $r(\mathrm{f}((T-\mathrm{g}(e)) / \sigma) \mathrm{g}$ ' $(e) / \sigma-\mathrm{f}$ ' $((T-\mathrm{g}(e)) /$ $\left.\sigma) \mathrm{g}^{\prime}(e) \mathrm{g}^{\prime}(e) / \sigma^{2}\right)<0$, so $\mathrm{e}^{*}$ it is also a global maximum effort for the executive.

\section{An empirical test}

Researchers cannot usually observe the minimum profit level to continue in firm $T$, but it can be observed the executives that have been dismissed, those whose firm's profits falls below the imposed limit, $P<T=-\sigma\left|\mathrm{f}^{-1}(\sigma / r)\right|+\mathrm{g}\left(e^{*}\right)$ by condition i) or in terms of the standardized profits, $\left.P_{\mathrm{s}}=\left(P-\mathrm{g}\left(e^{*}\right)\right) / \sigma\right)<-\left|\mathrm{f}^{-1}(\sigma / r)\right|=T_{\mathrm{s}}$, being $T_{\mathrm{s}}$ the threshold for standardized profits, and then, perfectly related with the dismissal probability. Therefore the dismissal probabilities, increases with performance risk $\sigma, \partial T_{s} / \partial \sigma=\partial \mathrm{f}^{-1}(\sigma / r) / \partial \sigma \geq 0$, and decreases with rents $r$, $\partial T_{s} / \partial r=\partial \mathrm{f}^{-1}(\sigma / r) / \partial r \leq 0$, due that $\mathrm{f}^{\prime}(z) \geq 0$ when $z \leq 0$. We can define the variable $Y=T_{\mathrm{s}}$ $P_{\mathrm{s}}$, but unfortunately researchers will have several difficulties to observe $T_{\mathrm{s}}$. Due that that it, from Taylor expansion we can approximate the function above as: 


$$
\mathrm{Y}^{*}=a+c \sigma+d r+h P_{\mathrm{s}}+\varepsilon
$$

expecting that $c>0, d<0$ and $h<0$. $Y^{*}$ corresponds to the latent variable of a logit or pobit model, depending on the assumptions made regarding the distribution of the error term $\varepsilon$.

Dismissal probabilities and consequently $Y^{*}$ :

1. Decreases with profits, $\mathrm{P}$ (Hypothesis 1 implies $h<0$ ).

2. Increases with risk, $\sigma$ (Hypothesis 2 implies $c>0$ ).

3. Decreases with executive rents, $r$ (Hypothesis 3 implies $d<0$ ).

\section{Extensions and limitations}

1. We do not exclude other possible solutions to the frim's problem. More concretely,

$$
T=+\sigma\left|\mathrm{f}^{-1}(\sigma / r)\right|+\mathrm{g}\left(e^{*}\right)
$$

This solution implies, $T-\mathrm{g}\left(e^{*}\right)>0$, fulfilling the first order condition and in some particular cases, (g" $\left.\left(e^{*}\right)<r \mathrm{f}^{\prime}\left(\mathrm{f}^{-1}(\sigma / r)\right) / \sigma^{2}<0\right)$, also fulfills the second order condition. If this point could be implemented as a global maximum for the executive, it imposes dismissal probabilities greater than fifty percent and consequently higher than those imposed in the solution proposed and usually found by the empirical evidence (Murphy,1999). In the text, all the hypotheses have been developed assuming that firms do not implement this solution.

2. One can consider the presence of incentives: $s=a+b$ P. The first order condition of the executive decisions can be reformulated as:

$$
\mathrm{g}^{\prime}(\mathrm{e})(\mathrm{b}+\mathrm{rf}((\mathrm{T}-\mathrm{g}(\mathrm{e})) / \sigma) / \sigma)=1
$$

so in order to implement the optimal level of effort, $e^{*}$, and given that $\mathrm{g}^{\prime}\left(e^{*}\right)=1$, then $T_{\mathrm{s}}=\mathrm{f}^{-1}((1-$ b) $\sigma / r$ ). All the relationships above are maintained. If we assume that the incentives depend on the number of team members, $b=1 / \mathrm{n}$, then the dismissal probability increases with the size of the top management team, similar result than those proposed in Hypothesis 4.

3. Further work is needed to understand the market equilibrium with the contracts analyzed before, in line with the former work of Shapiro and Stiglitz (1984), or for example, which combination of incentive systems (dismissal policies, bonuses, stock options...) could be optimal under different circumstances. How to modelize in a manageable way risk aversion considerations, costs of dismiss executives, wealth and rents limitations, is something that in the actual literature, as far as we know, has not been done yet. 


\section{APPENDIX 2}

\section{The Ranking of Job Positions}

\begin{tabular}{|c|c|}
\hline ORIGINAL TITLE & LEVEL \\
\hline ADMINISTRATIVE VICEPRESIDENT & 4 \\
\hline APPOINTED & 4 \\
\hline ASSISTANT CHIEF COUNSEL & 4 \\
\hline ASSISTANT GENERAL COUNSEL & 4 \\
\hline ASSISTANT GENERAL MANAGER & 4 \\
\hline ASSISTANT SECRETARY & 4 \\
\hline ASSISTANT TO THE PRESIDENT & 4 \\
\hline ASSISTANT TO THE TREASURER & 4 \\
\hline AUDITOR & 4 \\
\hline CHAIRMAN OF THE BOARD & 1 \\
\hline CHIEF ACCOUNTING OFFICER & 2 \\
\hline CHIEF ADMINISTRATIVE OFFICER & 2 \\
\hline CHIEF EXECUTIVE OFFICER & 1 \\
\hline CHIEF FINANCIAL OFFICER & 2 \\
\hline CHIEF OPERATING OFFICER & 2 \\
\hline CONSULTANT & 4 \\
\hline CONTROLLER & 4 \\
\hline DEPUTY CHAIRMAN & 2 \\
\hline DIVISION PRESIDENT & 3 \\
\hline EXECUTIVE OFFICER & 3 \\
\hline EXECUTIVE VICE PRESIDENT & 2 \\
\hline FINANCIAL VICE PRESIDENT & 3 \\
\hline GENERAL ATTORNEY & 4 \\
\hline GENERAL MANAGER & 4 \\
\hline GENERAL OFFICER & 4 \\
\hline GROUP PRESIDENT & 3 \\
\hline GROUP VICE PRESIDENT & 3 \\
\hline LEGAL COUNSEL & 4 \\
\hline MANAGING DIRECTOR & 4 \\
\hline OFFICE DIRECTOR & 2 \\
\hline PRESIDENT & 1 \\
\hline PRINCIPAL ACCOUNTING OFFICER & 2 \\
\hline SECRETARY & 4 \\
\hline SENIOR EXECUTIVE VICE PRESIDENT & 2 \\
\hline SENIOR FINANCIAL OFFICER & 2 \\
\hline SENIOR VICE PRESIDENT & 2 \\
\hline SUBSIDIARY OFFICER & 3 \\
\hline TREASURER & 4 \\
\hline VICE CHAIRMAN OF THE BOARD & 2 \\
\hline VICE PRESIDENT & 3 \\
\hline
\end{tabular}

In the category of TOPOFFICER is any executive that is the highest ranking officer in the firm at the time. This person most often holds the title "CEO". Initially, all TOPOFFICERs fell into Level 1. 
Table 1

Descriptive Statistics

Overall Sample, Compared with Salary Subsample

\begin{tabular}{|c|c|c|c|c|}
\hline \multirow[b]{2}{*}{ Variable } & \multicolumn{2}{|c|}{ Overall Sample } & \multicolumn{2}{|c|}{$\begin{array}{l}\text { Subsample with Salary } \\
\text { Information Available }\end{array}$} \\
\hline & Mean & Std. Dev. & Mean & Std. Dev. \\
\hline Exit (0/1) & 0.132 & 0.339 & 0.110 & 0.314 \\
\hline ROA & 0.028 & 0.154 & 0.027 & 0.153 \\
\hline Shareholder Return & 0.142 & 0.547 & 0.140 & 0.564 \\
\hline Total Risk & 0.030 & 0.020 & 0.032 & 0.019 \\
\hline TMT Size & 11.981 & 7.599 & 9.719 & 5.186 \\
\hline Log(Salary) & & & 12.247 & 0.769 \\
\hline Top Officer $(0 / 1)$ & 0.116 & 0.320 & 0.221 & 0.415 \\
\hline Level $1(0 / 1)$ & 0.061 & 0.394 & 0.100 & 0.301 \\
\hline Level 2 (0/1) & 0.228 & 0.420 & 0.308 & 0.420 \\
\hline Level 3 (0/1) & 0.495 & 0.500 & 0.355 & 0.500 \\
\hline Level $4(0 / 1)$ & 0.101 & 0.300 & 0.016 & 0.120 \\
\hline Industry ROA & 0.030 & 0.017 & 0.030 & 0.017 \\
\hline Market Return & 0.218 & 0.263 & 0.220 & 0.266 \\
\hline Top Officer Age & 56.002 & 8.448 & 55.753 & 8.812 \\
\hline Executive Age & 50.799 & 9.211 & 52.034 & 9.018 \\
\hline Sample Tenure & 1.788 & 1.591 & 2.106 & 1.609 \\
\hline New $(0 / 1)$ & 0.136 & 0.342 & 0.051 & 0.219 \\
\hline Log(Sales) & 5.310 & 2.296 & 4.842 & 2.111 \\
\hline Log(Assets) & 5.574 & 2.216 & 5.102 & 2.027 \\
\hline Observations & & 305 & & 761 \\
\hline
\end{tabular}


Table 2

The Probability of Executive Turnover

Dependent Variable: Exit

\begin{tabular}{|c|c|c|c|}
\hline Variables & Model 1 & Model 2 & Model 3 \\
\hline Constant & $-3.290^{* *}$ & $-3.262^{* *}$ & -2.621 \\
\hline ROA & $-0.619 * *$ & $-0.662 * *$ & $-1.191 * *$ \\
\hline Shareholder Return & $-0.171 * *$ & $-0.223^{* *}$ & -0.039 \\
\hline Total Risk & $9.894 * *$ & $10.689 * *$ & $13.325^{* *}$ \\
\hline TMT Size & $0.030 * *$ & $0.032 * *$ & $0.028 * *$ \\
\hline $\log ($ Salary $)$ & & & $-0.216^{*}$ \\
\hline Top Officer (0/1) & $-0.919 * *$ & $-0.942 * *$ & $-0.954 * *$ \\
\hline Level $1(0 / 1)$ & -0.198 & -0.262 & -0.109 \\
\hline Level $2(0 / 1)$ & 0.032 & -0.026 & -0.008 \\
\hline Level $3(0 / 1)$ & $0.275^{* *}$ & $0.235^{*}$ & 0.192 \\
\hline Industry ROA & & $-5.790^{*}$ & -6.972 \\
\hline Market Return & & $1.036^{* *}$ & $0.862 *$ \\
\hline Industry Indicator Variables & & YES** & YES** \\
\hline Top Officer Age & $-0.016^{* *}$ & $-0.018 * *$ & $-0.010^{*}$ \\
\hline New (First Year Observed) & 0.070 & 0.069 & $-0.533^{*}$ \\
\hline Executive Age & $0.039 * *$ & $0.042 * *$ & $0.038^{* *}$ \\
\hline Sample Tenure & $-0.097 * *$ & $-0.093 * *$ & $-0.214 * *$ \\
\hline Log(Sales) & -0.013 & -0.001 & 0.086 \\
\hline Log(Assets) & -0.020 & -0.032 & -0.025 \\
\hline Observation Year Indicators & YES** & YES** & YES** \\
\hline Log-Likelihood & $-4,750.09$ & $-4,706.28$ & $-1,865.22$ \\
\hline$\chi^{2}$ & $506.17 * *$ & $593.80 * *$ & $280.01 * *$ \\
\hline Number of Observations & 12,805 & 12,805 & 5,761 \\
\hline
\end{tabular}

$* *$, , significantly different from zero at $1 \%, 5 \%$ respectively. The level of significance associated with the industry parameters derives from a multivariate likelihood ratio test where the restricted model is without the industry parameters. 
Table 3

Regression Analysis of the Determinants of Firm Performance

\begin{tabular}{|c|c|c|}
\hline \multirow[b]{2}{*}{ Variable } & \multicolumn{2}{|c|}{ DEPENDENT VARIABLES } \\
\hline & Shareholder returns & Return on Assets (ROA) \\
\hline Constant & -0.045 & 0.017 \\
\hline Before year -1 & 0.003 & -0.013 \\
\hline Year -1 & -0.044 & -0.018 \\
\hline Year 0 & $0.193 * *$ & 0.029 \\
\hline Year 1 & 0.017 & 0.015 \\
\hline After year 1 & -0.057 & 0.005 \\
\hline Various changes & -0.109 & $-0.033 *$ \\
\hline Market Return & $0.827 * *$ & \\
\hline Industry ROA & & -0.064 \\
\hline $\log ($ Sales $)$ & 0.031 & $0.089 * *$ \\
\hline Log(Assets) & -0.031 & $-0.072 * *$ \\
\hline Total Risk & -0.364 & $-1.483 * *$ \\
\hline $\mathrm{R}^{2}$ & 0.1537 & 0.2643 \\
\hline F value $(10,1253)$ & $22.75 * *$ & $45.01 * *$ \\
\hline $\begin{array}{l}\text { Number of } \\
\text { Observations }\end{array}$ & 1,264 & 1,264 \\
\hline
\end{tabular}

**, *, significantly different from zero at $1 \%$ and $5 \%$. 


\section{Figure 1}

\section{The Determinants of Dismissal Probabilities}

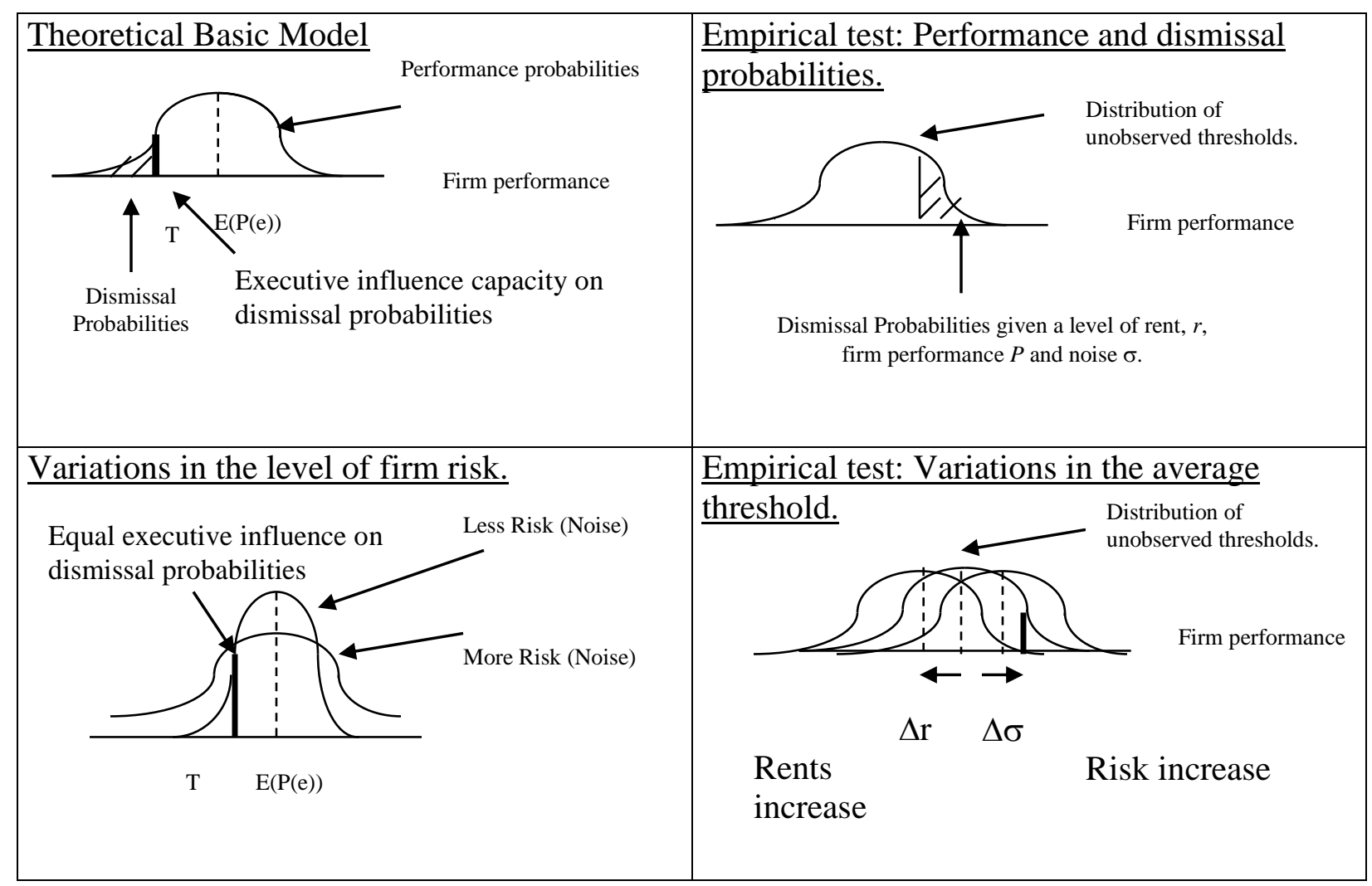

e- Executives actions.

P- Firm performance.

$\mathrm{E}(\mathrm{P}(\mathrm{e}))$ - Expected firm performance as a function of executive actions.

$\mathrm{T}$ - Performance threshold.

$\mathrm{r}$ - Rents.

$\sigma$ - Performance noise.

In Appendix A, all of these implications are derived from a simple efficiency wage model. 
Figure 2

Determinants of Executives Motivation According From an Efficiency Wage Perspective
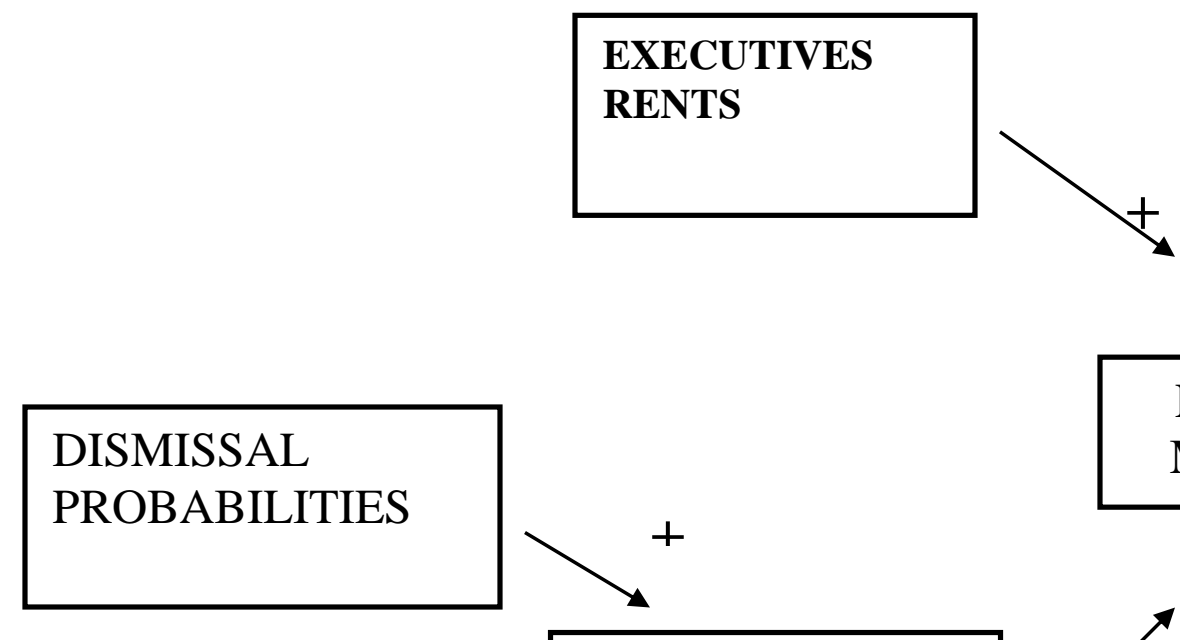

\section{EXECUTIVES MOTIVATION}

PERFORMANCE RISK

INFLUENCE

CAPACITY ON

DISMISSAL

PROBABILITIES

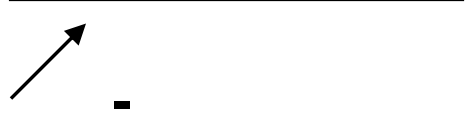

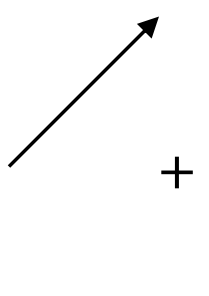

